DOI 10.18551/rjoas.2019-10.24

\title{
FACTORS AFFECTING THE DECISION OF FARMERS IN SELECTING WHITE PEPPER MARKETING CHANNELS
}

\author{
Pranoto Yudi Sapta*, Purwasih Rati \\ Department of Agribusiness, Faculty of Agriculture, Fisheries and Biology, \\ Bangka Belitung University, Indonesia \\ `E-mail: udhei sapta@yahoo.com
}

\begin{abstract}
The existence of a pattern of price fluctuations that is relatively pattern less throughout the year, causing the pepper commodity to be less attractive for farmers to be warehoused. The research objective was to analyze the factors influencing the decision of white pepper farmers in choosing the marketing channel of the warehouse receipt system in Bangka Belitung Islands Province. The study was conducted in Central Bangka Regency and Bangka Regency, Bangka Belitung Islands Province. The number of respondents of white pepper farmers in this study were 32 people chose non warehouse receipt system and 30 people chose warehouse receipt system. The sampling technique used was purposive sampling. Factors influencing the decision of white pepper farmers in choosing the marketing channel of the warehouse receipt system were analyzed using quantitative analysis using a binary logistic model. The results of the analysis showed that the age of the farmer, the education of the farmer, the experience of farmers in farming white pepper, land area, and the selling price of white pepper increased the chances of farmers in choosing marketing channels through the warehouse receipt system. The number of dependents and quality requirements reduced the opportunity for farmers to choose marketing channels through the warehouse receipt system.
\end{abstract}

\section{KEY WORDS}

Decision, farmer, marketing channels, non-warehouse receipt system, warehouse receipt system, white pepper.

The development of pepper plantations in the Bangka Belitung Islands Province has indeed experienced ups and downs, but for the people of the Province of Bangka Belitung Islands the existence of pepper as one of the superior products has brought a long history to people lives. Pepper cultivation activities have been carried out down and down by the people of the Bangka Belitung Islands Province and have become a culture for the community. History has noted that the pepper commodity in the Bangka Belitung Islands Province once made a very large contribution to the regional economic growth. This can be seen from the extent of pepper plantations at that time, namely in 1990 the area of pepper plantations reached 90,000 hectares, but ten years later the heyday tended to decrease marked by a decreasing area (Ministry of Trade Republic of Indonesia 2014). Even in 2017, the area of pepper plantations in this province has decreased by only 52,247 hectares (BPS Province of Bangka Belitung Islands 2018).

Pepper plantations in Bangka Belitung Islands Province have experienced ups and downs, where the ups and downs of pepper plantations in the Province is influenced by many factors, both external and internal. One of the internal factors causing the decline in pepper production in the Bangka Belitung Islands Province is the existence of a local Government policy through Perda No. 6/2001 on Management of General Mining, which states that mining businesses can be managed by individuals. The existence of this policy causes an increase in the growth of individual mining businesses that require a large workforce, so that pepper farmers, especially laborers and small farmers, are turning into mining workers. They are more interested in becoming miners because the income they earn is greater and they can get wages every day. Meanwhile, to get income from pepper plantations requires a relatively long time. Another contributing factor is that many pepper 
plantations have turned into palm oil plantations, both those managed by large companies and those managed by the people. Therefore, many pepper plantations are no longer used so that the plantation area is reduced (Ministry of Trade Republic of Indonesia 2014).

The development of pepper prices in the Bangka Belitung Islands Province always fluctuates, but shows an uncertain pattern. For example in rice plants, usually the price of rice in the harvest season tends to be lower, in contrast to the dry season the price of rice increases and this happens almost throughout the year. However, the price of pepper during the harvest season does not necessarily decrease because the price fluctuation is not patterned. Pepper harvest season usually occurs in July to September, should be in the period from July to September the price of pepper will decrease significantly, but what happened pepper prices actually increased in 2013 and 2014. Meanwhile, in 2015 to 2017 in the same period Pepper prices tend to decrease (Figure 1).

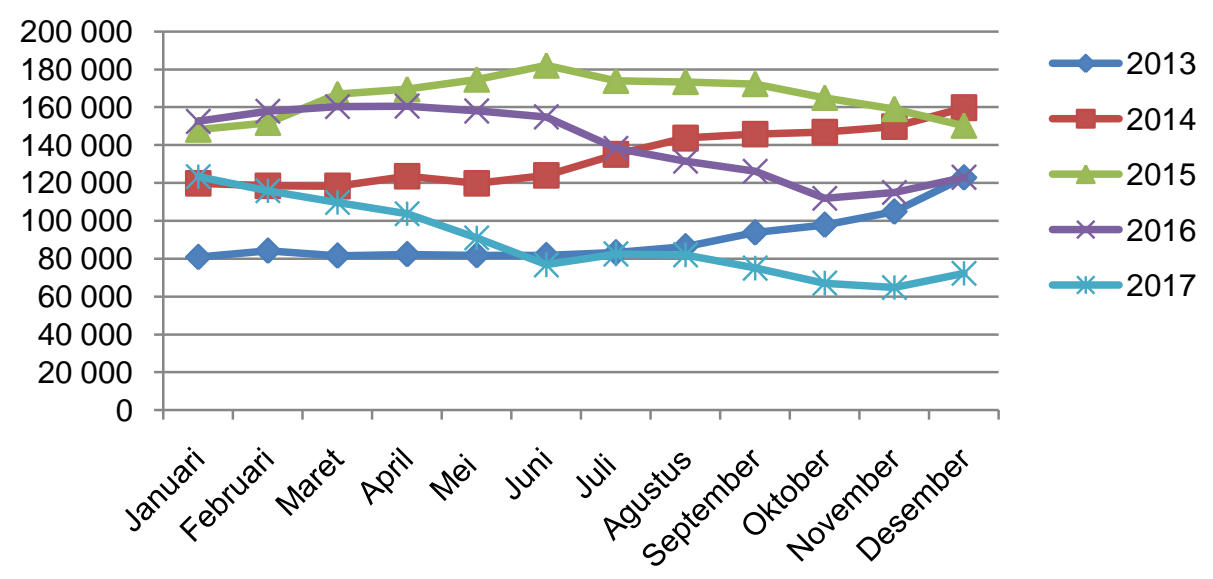

Figure 1 - White Pepper Prices at the Farmer Level of the Bangka Belitung Islands Province, 2013-2017 (Source: IPC, 2018)

The existence of a pattern of price fluctuations that is relatively pattern less throughout the year, causing the pepper commodity to be less attractive for farmers to be warehoused. Another factor that causes pepper commodities to be less attractive for farmers to be warehoused is the culture of storing pepper commodities that have been carried out by some farmers, but the storage of pepper commodities is done in the farmer's own warehouse or kept at home, so farmers do not incur costs, whereas for storing pepper in the SRG warehouse costs money (Ministry of Trade Republic of Indonesia 2014). The market becomes an estuary in the implementation of the warehouse receipt system, but in reality farmers are still difficult to access directly the existing commodity markets, so farmers are accustomed to the role of intermediaries so that the prices obtained are not optimal. This condition raises the suspicion that factors that influence farmers' decision to choose marketing through warehouse receipts include the culture of storing pepper and transaction costs. However, it needs to be proven statistically. Therefore, it is important to study the factors that influence the decision of white pepper farmers in choosing the marketing channel of the warehouse receipt system.

Research on the factors that influence marketing channel selection decisions has been widely carried out including Mabuza (2013) analyzing the effect of transaction costs on the selection of mushroom marketing channels in Swaziland. The model used to answer the research objectives is the Probit model. The results show that farmers 'decisions in choosing mushroom marketing channels are influenced by the level of education, access to market price information, farmers' bargaining position and farmer group membership.

Juliaviani (2016) examined the effect of transaction costs on the selection of Gayo coffee marketing channels in Aceh Province using a quantitative analysis with a probit model approach. The results show that transaction costs that affect farmers' opportunities in 
choosing marketing channels to cooperative traders (exporters) in Central Aceh District show the time to find price information and dummy access to prices reduces the opportunity for farmers to choose to sell to cooperative traders (exporters), conversely the prices received by farmers increase the chances of farmers choosing to sell to cooperative traders (exporters). Transaction costs that affect farmers 'opportunities in choosing marketing channels to cooperative traders (exporters) in Bener Meriah Regency, namely prices received by farmers and dummy access to credit, increase farmers' chances of choosing to sell to cooperative traders (exporters), while the longer payment from traders reduces opportunities for farmers to choose to sell to cooperative traders (exporters).

Harahap et al. (2018) analyze the factors that influence the decision making of thorny palm farmers in choosing marketing channels using the Logit model. The results of the analysis show that the experience of farming has a significant effect on the decision making of thorny palm farmers in choosing marketing channels, while the cash requirements, formal education of farmers, distance to the place of sale, number of family dependents, and land area have no significant effect on decision making in selecting marketing channels.

Putri et al. (2018) analyzed efficiency and factors that influenced the choice of the Vanda Douglas cut orchid marketing channel in Bogor Regency. The results show that the decision of farmers to choose the marketing channel for Vanda Douglas cut orchids is influenced by the age of the farmer, the selling price of the orchid, the length of the farm, and the area of land.

\section{LITERATURE REVIEW}

Based on the 2016 Republic of Indonesia Government Regulation, warehouses are all immovable and immovable rooms for the purpose of not being visited by the public, but for special use as a place for storing goods that can be traded publicly and fulfilling other conditions stipulated by the Minister. Meanwhile, warehouse receipts are proof of ownership of goods stored in the Warehouse that are issued by the Warehouse Manager. Based on the warehouse definition and warehouse receipt, the definition is obtained that the warehouse receipt system is an activity related to the issuance, transfer, guarantee, and completion of the Warehouse Receipt transaction. According to the 2006 RI Law, the Warehouse Receipt System is one of the important and effective instruments in the trade finance system. The Warehouse Receipt System can facilitate the provision of credit to businesses with inventory collateral or goods stored in warehouses. The Warehouse Receipt System is also useful in stabilizing market prices by facilitating sales methods that can be carried out throughout the year. In addition, the Warehouse Receipt System can be used by the Government to control national prices and inventories.

According to rules of Trade Ministry (2011), goods that can be stored in warehouses for issuance of warehouse receipts meet at least the requirements of having a minimum shelf life of 3 months; meet certain quality standards, and a minimum amount of goods stored.

Transaction costs can be interpreted into 3 broader categories (Hobbs 1997), namely (1) information retrieval costs, (2) negotiation and bargaining costs, and (3) monitoring and implementation costs. The cost of searching information consists of searching for market price information, price uncertainty, price knowledge, and difficulty finding price information. Negotiation and bargaining costs consist of time spent transacting with traders, late transaction fees, and land area. Monitoring and implementation costs consist of the speed of payment from traders, the speed of payment from farmers, trust in traders, trust in cooperatives, the existence of official contracts if sold to traders, and the existence of official contracts if sold to cooperatives.

\section{METHODS OF RESEARCH}

This research was conducted in Central Bangka Regency and Bangka Regency, Bangka Belitung Islands Province. The study was conducted from March to September 2019. The research method used in this study was a survey method. 
The sampling technique used was purposive sampling. Sub populations in this study are farmers who sell to warehouse receipt systems and non-warehouse receipt systems. The number of farmers who were respondents in the study could be seen in Table 1.

Table 1 - Number of Respondent Farmers

\begin{tabular}{cccc}
\hline No & Regency/City & Warehouse receipt system & Non-warehouse receipt system \\
\hline 1 & Central Bangka & 9 & 17 \\
2 & Bangka & 21 & 15 \\
\hline & Total & 30 & 32 \\
\hline
\end{tabular}

Factors influencing the decision of white pepper farmers in choosing marketing channels through the warehouse receipt system were analyzed using quantitative analysis using a binary logistic model, with the following form of equation:

$$
Y_{i}=\beta_{0}+\beta_{1} X_{1}+\beta_{2} X_{2}+\beta_{3} X_{3}+\beta_{4} X_{4}+\beta_{5} X_{5}+\beta_{6} X_{6}+\beta_{7} D_{1}+\beta_{8} D_{2}+\beta_{9} D_{3}+\beta_{10} D_{4}+e
$$

Where: $Y=$ Marketing channel $\left(1=\mathrm{SRG}, 0=\right.$ non SRG); $X_{1}=$ Farmer's age (years); $X_{2}=$ Farmer Education (years); $X_{3}=$ White pepper farming experience (years); $X_{4}=$ Number of dependents (people); $X_{5}=$ Land area (ha); $X_{6}=$ Selling price of white pepper (IDR $/ \mathrm{kg}$ ); $D_{1}=$ Dummy quality requirements $(1=0=$ none $) ; D_{2}=$ Dummy culture saves pepper $(1=$ there, $0=$ none); $D_{3}=$ Dummy time searching for pepper information ( $1=$ long $0=$ not long); $D_{4}=$ Dummy land ownership status $(1=$ owner, $0=$ tenant); $E=$ Error term.

\section{RESULTS AND DISCUSSION}

In order to know the factors that influence white pepper farmers in choosing marketing channels through the warehouse receipt system in the Bangka Belitung Islands Province, the model used to analyze it is the binary logistic model with the help of the SPSS 16.0 program. The test results show that the factors that have a significant effect on the selection of marketing channels through the warehouse receipt system are the age of the farmer, the number of dependents of the farmer, farmer education, the experience of farmers working on white pepper, land area, selling price, and quality requirements, while searching for price information, pepper save culture, and land ownership status have no significant effect. More clearly the results of the analysis can be seen in Table 2 .

Based on the results in Table 2, the $R^{2}$ value of 0,905 is obtained, which means that $95 \%$ of the variations in the decision of farmers in the selection of white pepper marketing channels through the warehouse receipt system can be explained by the age of the farmer, the number of dependents of the farmer, farmer education, farmer experience, land area, selling price, quality requirements, pepper save culture after harvest, and land ownership status, while the remaining $5 \%$ is explained by other factors outside the model.

Based on the results of the analysis obtained the estimated parameter values on the age variable of farmers that is equal to 0,193 and a significant level of 0,062 . The regression results show that the significant value is less than the specified real level. This means that the farmer age variable has a significant positive effect on farmers' decisions in choosing marketing channels through the warehouse receipt system. Farmer age variable has an odd ratio value of 1,213 , which means that if the respondent farmer's age increases by 1 year, the opportunity for farmers to choose the warehouse receipt system marketing channel increases 1,213 times compared to the non warehouse and warehouse marketing channel. Farmer respondents who chose marketing channels through the warehouse receipt system had a productive age of $96,67 \%$, while there were $3,33 \%$ of unproductive age. Farmer respondents who choose non-warehouse receipt system marketing channels that have a productive age are $90,63 \%$, while the remaining $9,38 \%$ have a relatively productive age. This shows that there are more farmers who choose non-productive warehouse receipt channel marketing systems than farmers who choose marketing channels through the warehouse receipt system. For the older farmers, it tends to be difficult to accept new innovations. 
Table 2 - Regression Results Factors That Influence Farmers' Decisions on the Selection of Marketing Channel Warehouse Receipt Systems

\begin{tabular}{clccccc}
\hline No & Variable & B & Wald & df & Sig. & Exp(B) \\
\hline 1 & Constant & $-46,537$ & 0,000 & 1 & 0,998 & 0,000 \\
2 & Age & 0,193 & 3,493 & 1 & $0,062^{\mathrm{b}}$ & 1,213 \\
3 & Education & 0,257 & 5,626 & 1 & $0,018^{\mathrm{a}}$ & 3,514 \\
4 & Farming Experience & 0,169 & 2,649 & 1 & $0,104^{\mathrm{c}}$ & 1,184 \\
5 & Numbers of Dependents & $-3,506$ & 6,072 & 1 & $0,014^{\mathrm{a}}$ & 0,030 \\
6 & Surface Area & 2,387 & 2,431 & 1 & $0,119^{\mathrm{c}}$ & 10,884 \\
7 & Selling Price & 0,001 & 3,131 & 1 & $0,077^{\mathrm{b}}$ & 1,001 \\
8 & Quality Requirement & $-9,402$ & 5,033 & 1 & $0,025^{\mathrm{a}}$ & 0,000 \\
9 & Save Culture after Harvest & $-23,095$ & 0,000 & 1 & 0,998 & 0,000 \\
10 & Time Looking for Prices & $-15,104$ & 0,000 & 1 & 0,999 & 0,000 \\
11 & Land Ownership Status & 6,838 & 0,433 & 1 & 0,510 & 932,226 \\
\hline
\end{tabular}

Note: ${ }^{a}$ significant at $5 \%$ real level, ${ }^{b}$ significant at $10 \%$ real level, ${ }^{c}$ significant at $15 \%$ real level.

Education has a significant effect on farmers' decisions in choosing marketing channels for warehouse receipt systems. This can be seen from the significant value of 0,018 , which means it is less than the specified real level. The estimated parameter value of the farmer education variable is 0,257 and this value indicates that the farmer education variable has a significant positive effect on the farmer's decision in choosing the marketing channel for the warehouse receipt system. Odd ratio value obtained from the regression results is equal to 3,514 , which means that if farmer education increases 1 year, the opportunity for farmers to choose a warehouse receipt system marketing channel increases 3,514 times compared to non-warehouse receipt system marketing channels. According to Putri et al. (2018) the level of education influences the attitude of farmers in receiving new information and innovations. The higher the education of farmers, they are expected to choose more profitable marketing channels.

Education has a significant effect on farmers' decisions in choosing marketing channels for warehouse receipt systems. This can be seen from the significance value of 0,018 , which means the significance value is less than the specified real level. The estimated parameter value of the farmer education variable is 0,257 and this value indicates that the farmer education variable has a significant positive effect on the farmer's decision in choosing the marketing channel for the warehouse receipt system. Odd ratio value obtained from the regression results is equal to 3,514, which means that if farmer education increases 1 year, the opportunity for farmers to choose a warehouse receipt system marketing channel increases 3,514 times compared to non-warehouse receipt system marketing channels. According to Putri et al. (2018) that the level of education influences the attitude of farmers in receiving new information and innovations. The higher the education of farmers, the farmers are expected to choose more profitable marketing channels.

In addition to farming experience, the number of dependents of farmers is also one of the factors that influence the decision of white pepper farmers in choosing marketing channels through the warehouse receipt system. Based on the regression results obtained significant value on the variable number of dependents of farmers amounting to 0,014 . This value indicates that the variable number of dependents significantly influences the decision of farmers in choosing the marketing channel of the warehouse receipt system. This is because the significant value is less than the specified real level $(\alpha=15 \%)$. The estimated parameter value of the number of dependents of farmers is $-3,506$. The negative sign on the value of the alleged parameter indicates that the variable number of dependents of the farmer has a significant negative effect on the decision of the farmer in choosing the marketing channel of the warehouse receipt system. In order to know the magnitude of the effect of the variable number of dependents of farmers on the decision of farmers in choosing the marketing channel of the warehouse receipt system, it can be seen from the value of odd 
ratio. Odd ratio value obtained from the regression results is equal to 0,030 . This shows that if the number of dependents of the farmer increases by 1 person, the opportunity for farmers to choose the warehouse receipt system marketing channel will decrease by 0,030 times compared to the non-warehouse receipt system marketing channel. This means that the more the number of dependents of farmers, the opportunity for farmers to choose nonwarehouse receipt system marketing channels will increase. The average number of dependents owned by respondent farmers who choose non-warehouse receipt system marketing channels is 4 people, while the average number of dependents owned by respondent farmers who choose warehouse receipt system marketing channels is 2 people.

The selection of white pepper marketing channels through the warehouse receipt system is also influenced by land area. This can be seen from the significant value which is less than the determined real level, where the significant value is 0,119 and the real level used is $0,15(\alpha=15 \%)$. The estimated parameter value of the land area variable is 2,387 , where the positive sign indicates that the land area variable has a significant positive effect on farmers' decisions in choosing the marketing channel of the warehouse receipt system. Odd ratio value obtained is 10,884, which indicates that if the area of land increases by 1 hectare, the opportunity for farmers to choose a warehouse receipt system marketing channel increases 10,884 times compared to non-warehouse receipt system marketing channels. The average area of white pepper farming in the SRG marketing channel is 1,85 hectares, while the average area of farming on non SRG marketing channels is 0,88 hectares. This condition shows that the respondent farmers in the non-SRG marketing channel have smaller land than the respondent farmers in the SRG marketing channel. According to Putri et al. (2018) a wider area of land will produce a greater amount of production so that it will encourage farmers to choose more profitable marketing channels.

In addition, the decision of farmers in the selection of white pepper marketing channels through the warehouse receipt system is also influenced by the high and low selling prices. This can be seen from the significant value that is equal to 0,077 and this value is less than the real level that has been determined $(\alpha=10 \%)$. To find out whether the selling price has a positive or negative effect on the decision of farmers in choosing the marketing channel of the warehouse receipt system, it can be seen from the presumptive parameter sign on the selling price variable. The estimated parameter value of the land area variable is 0,001 . This value indicates that the selling price variable has a significant positive effect on farmers' decisions in choosing the warehouse receipt system marketing channel. Meanwhile the magnitude of the effect of selling price variables on farmers' decisions in choosing the warehouse receipt system marketing channel can be seen from the value of odd ratio. The magnitude of the odd ratio value on the selling price variable is equal to 1,001 . This condition shows that if the selling price increases Rp 1 per kilogram, the opportunity for farmers to choose the warehouse receipt system marketing channel increases 1,001 times compared to the non-warehouse receipt system marketing channel. According to Mabuza et al. (2013) that farmers will choose marketing channels that offer higher prices.

Another factor influencing the decision of white pepper farmers in the selection of marketing channels through the warehouse receipt system is the quality requirements of the dummy variable significance value of the quality requirements that is equal to 0,025 . Thus the quality requirements significantly influence farmers' decisions in choosing marketing channels through the warehouse receipt system. This condition is because the significance value is less than the specified real level $(\alpha=5 \%)$. Quality requirements have a significant negative effect on farmers' decisions in choosing marketing channels through the warehouse receipt system. This can be seen from the value of the alleged negative parameter which is equal to $-9,402$ which means that the quality requirements will reduce the opportunity for farmers to choose marketing channels through the warehouse receipt system. This shows that the existence of quality requirements will encourage farmers to prefer non-warehouse receipt system marketing channels.

The culture of storing white pepper in the farmer's own home has no significant effect on the decision of farmers in choosing marketing channels. This condition can occur because farmers who choose marketing channels through the warehouse receipt system or non 
warehouse receipt system have the majority of habits of storing white pepper at home. It can be seen that the number of farmers who choose marketing channels through the warehouse receipt system that has the habit of storing white pepper at home is 30 people (100\%), while the farmers who choose marketing channels through the non warehouse receipt system are 21 people $(65,63 \%)$.

Timing on looking for information on the price of white pepper also does not affect the decision of farmers in choosing marketing channels. This can happen because the majority of farmers who choose marketing channels through the warehouse receipt system and non warehouse receipt system do not need a long time to find price information.

The decision to choose marketing channels is also not influenced by land ownership status. The majority of white pepper farmers who choose marketing channels through the warehouse receipt system and non warehouse receipt system have their own land so farmers are free to choose who will sell white pepper. As many as 27 people (90\%) farmers who choose marketing channels through the warehouse receipt system have their own land and as many as 30 people (93.75\%) farmers who choose the non-warehouse receipt system marketing channels have their own land.

\section{CONCLUSION AND SUGGESTIONS}

Factors that influence farmers' decisions in choosing SRG and non-SRG marketing channels are farmers' age, farmer education, farming experience, number of dependents, land area, selling price, and quality requirements. Age, education, experience, land area and selling price increase the chances of farmers choosing SRG marketing channels, whereas the number of dependents and quality requirements reduce the chances of farmers choosing SRG marketing channels. The local government should be more intensive in promoting the Warehouse Receipt System to white pepper farmers in the Bangka Belitung Islands Province. There should be a special manager in the farmer group who can help white pepper farmers in the Warehouse Receipt System procedure so that they can facilitate farmers to access the white pepper commodity market.

\section{REFERENCES}

1. [BPS] Badan Pusat Statistik Provinsi Kepulauan Bangka Belitung. 2018. Provinsi Kepulauan Bangka Belitung dalam Angka. Provinsi Kepulauan Bangka Belitung (ID): Badan Pusat Statistik Provinsi Kepulauan Bangka Belitung.

2. Harahap J, Sriyoto. 2018. Faktor-faktor yang Mempengaruhi Pengambilan Keputusan Petani Salak dalam Memilih Saluran Pemasaran. Jurnal Agrisep. 17(1):95-106.

3. Hobbs J.E. 1997. Measuring the importance of transaction costs in cattle marketing. American Journal of Agricultural Economics. 79(4): 1082-1095.

4. [IPC] International Pepper Community. 2018. Pepper Statistical Yearbook 2017. Jakarta (ID): International Pepper Community.

5. Juliaviani N. 2016. Analisis Efisiensi Pemasaran Ekspor Kopi Arabika Gayo di Provinsi Aceh. [Skripsi]. Bogor (ID): Institut Pertanian Bogor.

6. Kemendag RI. 2014. Analisis Implementasi Sistem Resi Gudang Komoditi Lada. Jakarta (ID): Kementerian Perdagangan.

7. Mabuza ML, 2013. Effects of transaction cost on mushroom producers choice of marketing channels. SAJEMS NS. 17(1):207-219.

8. Permen RI. 2016. Lembaga Pelaksana Penjaminan Sistem Resi Gudang. Jakarta (ID): Pemerintah Republik Indonesia.

9. Permendag RI. 2011. Barang yang dapat disimpan di Gudang dalam Penyelenggaraan Sistem Resi Gudang. Jakarta (ID): Menteri Perdagangan.

10. Putri RK, Nurmalina R, Burhanuddin. 2018. Analisis Efisiensi and Faktor yang Mempengaruhi Pilihan Saluran Pemasaran. Jurnal Ilmiah Manajemen. 8(1):109-135.

11. Undang-undang RI. 2011. Perubahan Atas Undang-undang Nomor 9 Tahun 2006 Tentang Sistem Resi Gudang. Jakarta (ID): Kementerian Sekretariat Negara. 